\title{
PERANCANGAN MODEL LEAN MANUFACTURING UNTUK MEREDUKSI BIAYA DAN MENINGKATKAN CUSTOMER PERCEIVED VALUE
}

\author{
Suhendi, Dorina Hetharia dan Iveline Anne Marie \\ Program Studi Magister Teknik Industri Universitas Trisakti \\ e-mail: ignatiussuhendi@yahoo.com
}

\begin{abstract}
ABSTRAK
Menghadapi persaingan industri yang semakin ketat, perusahaan manufaktur berusaha meningkatkan daya saingnya dengan meningkatkan produktifitas, kualitas dan juga efisiensinya. Dalam proses produksi pembuatan produk, perusahaan juga menghadapi permasalahan terjadinya waste. Waste berdampak secara langsung kepada menurunnya produktivitas dan tingginya biaya produksi. Pendekatan yang dapat digunakan untuk mengatasi masalah tersebut adalah menerapkan lean manufacturing, yaitu konsep yang bertujuan untuk menghasilkan proses manufaktur yang lebih efisien dengan mengeliminasi semua unsur waste dalam proses pembuatannya. Penelitian ini bertujuan untuk mendapatkan hasil rancangan model lean manufacturing dengan menggunakan beberapa alat bantu yang sesuai untuk mereduksi biaya dan meningkatkan customer perceived value. Rancangan model perlu divalidasi dengan menggunakan kasus pada perusahaan manufaktur tertentu. Diharapkan rancangan model lean manufacturing dapat menjadi solusi bagi perusahaan manufaktur untuk dapat mereduksi biaya dan meningkatkan customer perceived value.
\end{abstract}

Kata kunci: lean manufacturing; waste; reduksi biaya; customer perceived value

\begin{abstract}
[Title: Designing Lean Manufacturing Model to Reduce Cost and Increase Customer Perceived Value] Facing the increasingly fierce industrial competition, manufacturing company in various fields always improve its competitiveness by increasing its productivity, quality and efficiency. In the production process of making products, the company also faces the problem of waste. Waste is directly affecting the decrease in productivity and high production costs. Tools that can be used to overcome the problem is to apply lean manufacturing, which is a concept that aims to produce more efficient manufacturing by eliminating all waste elements in the manufacturing process. In this research will be design lean manufacturing model by using some lean tools appropriate to reduce cost and improve customer perceived value. The design of the model needs to be validated using cases in certain manufacturing companies. It is expected that the design of lean manufacturing models can be a solution for manufacturing companies to be able to reduce costs and improve customer perceived value.
\end{abstract}

Keywords: lean manufacturing; waste; reduce costs; customer perceived value

\section{PENDAHULUAN}

Saat ini secara tidak langsung banyak perusahaan sudah mulai menerapkan beberapa elemen lean manufacturing, namun dalam perencanaan dan implementasinya kurang terstruktur dan tidak sistematis. Salah satu contoh adalah penekanan untuk mengurangi waste, tapi kurang jelas waste apa saja yang harus diminimasi, dan bagaimana pengukurannya. Waste adalah musuh utama lean manufacturing yang harus diidentifikasi dan diukur [1]. Waste dikategorikan menjadi 8 jenis yaitu waste produksi berlebih (over production), waktu tunggu (waiting time), gerakan yang tidak perlu (unnecessary motion), transportasi, proses yang tidak sesuai (inappropriate processing), inventori, cacat produk (defects) dan underutilized people [2].

Ada banyak keuntungan yang akan didapatkan dengan menerapkan lean manufacturing, disamping ada juga kekurangannya. Keuntungan yang didapatkan dengan menerapkan lean manufacturing antara lain adalah dapat meningkatkan produktivitas, pengurangan waste secara keseluruhan, reduksi biaya (cost reduction), pengurangan defects, dan peningkatan kualitas secara keseluruhan [3]. Sedangkan kekurangan lean manufacturing adalah tidak mudahnya mengimplementasikan lean dalam periode waktu yang singkat dikarenakan kompleksitas dan banyaknya aspek yang berpengaruh. Implementasi lean 
manufacturing membutuhkan waktu untuk mencapai hasil yang diinginkan.

Dengan menerapkan lean manufacturing tools and techniques, seperti Value Stream Mapping (VSM), Kaizen, 5S, Total Productive Maintenance, Just In Time, Kanban, dan tools lainnya, maka waste dan non-value added activity dapat diidentifikasi, prosedur kerja akan lebih baik, breakdown mesin juga akan menurun, kualitas produk yang dihasilkan akan lebih baik, waste yang dihasilkan juga akan menurun sehingga pada akhirnya akan berdampak langsung kepada reduksi biaya produksi.

Dalam banyak penelitian seputar lean manufacturing membahas tentang minimasi waste, eliminasi non value added activity, meningkatkan produktivitas, dan lainnya yang dampaknya berkutat hanya di internal perusahaan saja. Sedangkan untuk value secara eksternal yaitu untuk ke pelanggan masih sangat minim penelitiannya. Padahal teori lean adalah praktik produksi yang bertujuan untuk meminimalkan waste sepanjang seluruh value stream dan menciptakan lebih banyak nilai bagi pelanggan. Menurut lean, pemanfaatan apapun sumber daya yang tidak dianggap sebagai value bagi pelanggan adalah tujuan untuk perubahan atau eliminasi [4].

Perusahaan manufaktur yang bergerak dalam berbagai bidang, senantiasa menghasilkan produk dengan kualitas yang baik dan mengimplementasikan proses produksi yang efektif dan efisien sehingga biaya produksi yang dihasilkan rendah. Selama bertahun-tahun, perusahaan-perusahaan manufaktur telah tumbuh dan berkembang pesat menjadi perusahaan yang cukup kuat di market Indonesia dan saat ini telah diakui sebagai produsen lokal dan distributor yang terkemuka. Kombinasi antara ilmu pengetahuan dan teknologi manufaktur yang mutakhir akan tetap membuat perusahaan-perusahaan manufaktur berdedikasi untuk menyediakan produk-produk berkualitas dengan harga yang terjangkau.

Dalam proses produksi pembuatan produk, perusahaan manufaktur banyak menghadapi permasalahan terjadinya pemborosan (waste). Pemborosan tersebut berdampak secara langsung kepada menurunnya produktivitas dan tingginya biaya produksi. Karena banyaknya waste yang terjadi dan rendahnya produktivitas di proses produksi maka dibutuhkan solusi untuk mengatasi masalah tersebut, salah satunya dengan menerapkan lean manufacturing. Dalam penelitian ini akan dilakukan perancangan model lean manufacturing untuk mereduksi biaya dan meningkatkan customer perceived value. Untuk validasi perancangan model ini akan dilakukan di salah satu perusahaan manufaktur di bidang consumer goods. Selain itu akan digunakan beberapa lean tools yang sesuai untuk mengatasi permasalahan tingginya waste di perusahaan manufaktur tersebut. Diharapkan hasil perancangan model dalam penelitian ini dapat diimplementasikan dan menjadi solusi untuk perusahaan manufaktur di berbagai bidang untuk dapat mereduksi biaya dan meningkatkan customer perceived value.

Permasalahan yang terjadi di perusahaan manufaktur adalah banyak waste yang dihasilkan, dimana salah satu yang cukup signifikan adalah waste defects dimana hal ini mengakibatkan tingginya biaya produksi. Beberapa langkah untuk improvement sudah dilakukan, namun dikarenakan langkah-langkah tersebut tidak terorganisir dengan baik maka hasil perbaikan yang dirasakan tidak signifikan.

Permasalahan yang terjadi selanjutnya adalah pendekatan lean manufacturing yang umum digunakan perusahaan manufaktur saat ini lebih banyak menekankan kepada improvement di lingkup internal seperti peningkatan produktivitas, minimasi waste, dan sebagainya. Sedangkan untuk dampak secara eksternal masih sangat minim penelitiannya. Pendekatan lean manufacturing yang umum digunakan saat ini belum menekankan sampai ke perceived value yang didapatkan oleh customer.

Penelitian ini membahas permasalahan tingginya biaya akibat waste yang dihasilkan dan bagaimana meningkatkan customer perceived value. Tujuan dari penelitian ini adalah diperolehnya hasil rancangan model lean manufacturing untuk mereduksi biaya dan meningkatkan customer perceived value. Hasil penelitian diharapkan bisa bermanfaat untuk mereduksi waste yang akan berdampak pada 
reduksi biaya produksi suatu perusahaan manufaktur serta untuk meningkatkan customer perceived value mengenai sistem produksi lean yang lebih efektif dan efisien.

\section{TINJAUAN PUSTAKA}

Sistem produksi lean adalah konsep yang bertujuan untuk menghasilkan manufaktur yang lebih produktif dan lebih efektif dengan mengeliminasi semua unsur waste dalam proses pembuatannya [5]. Sistem produksi lean bertujuan untuk melakukan produksi dengan zero defects, untuk mengurangi biaya, untuk memenuhi permintaan pelanggan di saat yang tepat dan jumlah yang diinginkan, untuk menahan tidak ada kelebihan persediaan, dan untuk terus melakukan perbaikan berkesinambungan dengan menghilangkan pemborosan. Tujuan utama sistem lean adalah menghasilkan produk atau layanan dengan kualitas lebih tinggi dengan biaya terendah dan waktu paling minimal dengan menghilangkan pemborosan [6].

Pemborosan didefinisikan sebagai aktivitas manusia yang menggunakan sumber daya tapi tidak menciptakan nilai tambah [7]. "Muda" adalah pemborosan dalam bahasa Jepang dan diidentifikasi menjadi 7 tipe pemborosan yaitu overproduction, waiting time, transportation, unnecessary motion, inappropriate processing, inventory dan defects [8]. Tetapi belakangan pemborosan kedelapan ditambahkan yaitu "underutilized people" [9]. Deskripsi dari 8 tipe pemborosan antara lain [2]:

1. Produksi berlebih (overproduction); memproduksi terlalu banyak, berlebihan, dan terlalu dini.

2. Waktu menunggu (waste of waiting); secara langsung relevan ke aliran dan mungkin pemborosan paling krusial kedua.

3. Gerakan yang tidak perlu (waste of unnecessary motion); gerakan yang tidak perlu merujuk ke manusia dan layout.

4. Transportasi (waste of transportation); pergerakan material dan double handling adalah pemborosan, dimana akan berdampak ke produktivitas dan masalah kualitas.
5. Proses (waste of processing); pemborosan ini merujuk ke mesin dan proses yang tidak sesuai kualitas.

6. Persediaan berlebih (waste of inventory); inventori cenderung meningkatkan lead time, mencegah teridentifikasinya masalah, dan meningkatkan kebutuhan tempat yang akan berdampak ke komunikasi.

7. Produk cacat (waste of defects); kecacatan dalam kesalahan internal adalah scrap, rework dan delay. Sedangkan kesalahan eksternal adalah garansi, perbaikan dan service field.

8. Kreativitas karyawan yang tidak dimanfaatkan (waste of underutilized people); merujuk ke lebih banyak orang untuk dilibatkan dalam sebuah pekerjaan.

Value stream mapping merupakan metode lean manufacturing yang mengunakan simbolsimbol, metrics dan panah untuk menunjukkan dan memperbaiki aliran inventori dan informasi yang dibutuhkan untuk memproduksi produk atau jasa untuk sampai ke tangan pelanggan [10].

Value stream mapping terdiri dari 2 tipe yaitu [10]:

1. Current state map merupakan konfigurasi value stream produk saat ini, menggunakan ikon dan terminologi spesifik untuk mengidentifikasi waste dan area untuk perbaikan atau peningkatan (improvement).

2. Future state map merupakan cetak biru untuk transformasi lean yang diinginkan di masa yang akan datang.

Tools ini mampu menunjukkan error dalam suatu gambaran pada current state system dan digunakan untuk membuat kondisi yang ideal pada future state system. Value stream mapping juga merupakan suatu mapping tool yang digunakan untuk menggambarkan jaringan supply chain.

Value stream mapping tidak hanya memetakan aliran material tetapi juga aliran informasi yang menandakan dan mengontrol aliran material. Jalur aliran material dari suatu produk ditelusuri balik dari operasi akhir dan perjalanannya ke lokasi penyimpanan raw material. Aliran ini menggambarkan 
representasi fasilitas proses dari implementasi lean dengan cara membantu mengidentifikasi tahapan-tahapan non-value added atau waste.

Model bisa merupakan ikon, analog, atau simbolis [11]. Model ikonik adalah reproduksi benda fisik, biasanya dengan skala yang berbeda dan dengan kurang detail. Model analog adalah representasi yang menggantikan sifat atau fitur dari apa yang dimodelkan dengan cara alternatif sehingga modelnya bisa meniru apapun aspek hal yang sebenarnya sangat menarik bagi para modeller. Sedangkan model simbolis adalah representasi dari hubungan antara berbagai entitas atau konsep dengan simbol.

Terdapat 7 kriteria dimana model dapat dikatakan memiliki karakteristik yang baik antara lain [11]:

1. Simple, yaitu mudah dipahami khususnya oleh user atau decision maker atau bahkan oleh umum.

2. Complete, artinya menurut decision maker telah lengkap mencakup semua aspek atau elemen yang diharapkan atau diinginkan dari problematikanya.

3. Easy to manipulate, artinya mudah untuk mendapatkan jawaban dari model yang dihasilkan.

4. Adaptive, artinya model dapat beradaptasi dengan perubahan atau perkembangan situasi.

5. Easy to communicate with, artinya akan mudah bagi analyst (modeler) atau decision maker untuk meng-up date dan mengubah input dan cepat mendapatkan jawaban.

6. Appropriate for the situation studied, artinya model menghasilkan output yang relevan yaitu pada biaya terendah dan dalam time frame yang dibuthkan untuk pengambilan keputusan yang efektif.

7. Produce information, artinya yang relevan untuk pengambilan keputusan.

Pada dasarnya prinsip pemodelan adalah usaha untuk memperoleh model baru yang memiliki kemampuan lebih di dalam beberapa aspek. Pemodelan sistem berawal dari bagaimana mencoba memahami dunia nyata ini dan menuangkannya menjadi sebuah model dengan beragam metode yang ada. Tahapan pemodelan sistem dilakukan dengan fase-fase sebagai berikut [12]:

1. Identifikasi isu atau masalah, tujuan dan batasan.

2. Konseptualisasi model, dengan menggunakan ragam metode seperti diagram kotak dan panah, diagram sebab akibat, diagram stock and flow, atau diagram sekuens.

3. Formulasi model, merumuskan makna diagram, kuantifikasi dan atau kualifikasi komponen model.

4. Validasi model, mengamati kelogisan model dan membandingkan dengan dunia nyata.

5. Implementasi model, membuat skenarioskenario ke depan atau alternatif kebijakan, mengevaluasi ragam skenario atau kebijakan tersebut.

\section{METODE PENELITIAN}

Kerangka pemikiran dalam penelitian ini terdiri dari dalam 5 komponen utama, yaitu lean manufacturing, cost reduction dan customer perceived value, value dan customer. Untuk komponen cost reduction dikaitkan dengan 7 jenis waste. Untuk komponen lean manufacturing digunakan house of lean, sedangkan komponen untuk customer perceived value dikaitkan dengan pendekatan value analysis. Kelima komponen ini saling terkait satu dengan lainnya, dan untuk lebih detailnya kerangka pemikiran dapat dilihat diagram alir pada Gambar 1. Dari diagram alir Gambar 1 terlihat value menjadi komponen utama. Dengan penerapan lean manufacturing maka akan mereduksi cost dan disaat yang bersamaan akan meningkatkan value dari produk yang dihasilkan. Peningkatan value produk ini yang akan berdampak langsung ke customer sebagai pemakai produk tersebut, sehingga customer akan puas mendapatkan value dari produk sesuai dengan biaya yang dikeluarkan untuk membelinya.

Cost reduction berawal dari identifikasi waste yang dihasilkan, di mana waste-waste tersebut akan menimbulkan biaya. Waste overproduction akan menimbulkan direct material cost, indirect material cost dan inventory cost. Waste waiting time dan waste unnecessary motion akan menimbulkan cost 
direct labor cost dan indirect labor cost. Waste transportation akan menimbulkan material handling cost. Waste process akan menimbulkan cost direct material cost, indirect material cost dan energy cost. Waste inventory akan menimbulkan inventory cost. Waste defects akan menimbulkan direct material cost, indirect material cost dan cost of quality.

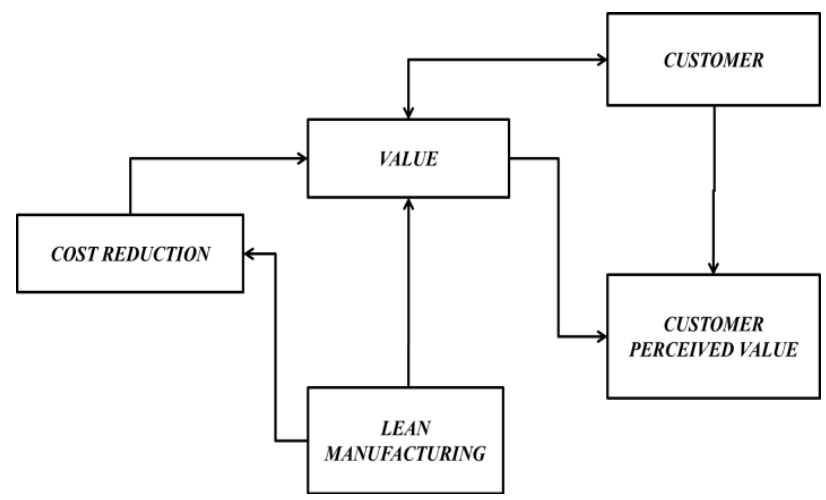

Gambar 1. Diagram Alir Kerangka Pemikiran

Lean manufacturing dibuat berdasarkan house of lean di mana didalamnya terdiri dari lean tools and techniques, antara lain Just In Time, SMED, TPM, 5S, Value Stream Mapping, Production Levelling, PokaYoke dan GT Layout. Dengan fondasi Heijunka, Standardized Process, Visual Control dan Continuous Improvement (Kaizen) serta dengan penerapan lean tools and techniques maka best cost, best quality, best delivery serta operational excellence bisa dicapai.

Customer perceived value berawal dari adanya ekspektasi dari pelanggan (customer expectations) seperti produk berkualitas, harga yang terjangkau, fungsi produk, customer service, dan reputasi perusahaan. Dari customer expectations diharapkan akan didapatkan customer perceived value, antara lain product value, service value, personnel value dan image value. Selanjutnya jika customer perceived value bisa dicapai maka akan didapatkan customer satisfaction. Terakhir setelah customer satisfaction dicapai akan menuju customer loyalty dimana kemungkinan pembelian kembali produk akan terjadi.

Tahapan awal penelitian dimulai dari studi pendahuluan dan literatur yang relevan dengan topik penelitian, perumusan masalah dan penentuan tujuan penelitian dan penentuan ruang lingkup penelitian. Tahapan berikutnya adalah studi literatur untuk tinjauan pustaka sesuai dengan topik penelitian. Selanjutnya dilakukan pengumpulan data, baik data primer maupun data sekunder.

Setelah pengumpulan data, dilanjutkan dengan analisis sistem untuk kondisi saat ini (as is) yang akan menjadi trigger untuk tahapan selanjutnya yaitu perancangan model lean manufacturing untuk reduksi biaya dan meningkatkan customer perceived value. Tahapan dalam perancangan model dimulai dari konseptualisasi model diagram alir. Kemudian dilanjutkan ke tahap formulasi model, yaitu merumuskan makna dari diagram alir model yang dibuat. Tahap selanjutnya sebelum model diimplementasikan di dunia nyata adalah validasi model. Jika model dinyatakan valid maka dapat dilanjutkan ke tahap implementasi model di dunia nyata dan dapat ditarik kesimpulan akhir hasil dari perancangan model secara keseluruhan. Untuk lebih jelasnya dapat dilihat diagram alir tahapan penelitian pada Gambar 2.

Pada penelitian ini dilakukan pengumpulan data primer dan data sekunder. Untuk pengumpulan data primer akan dilakukan kegiatan:

a. Observasi yaitu pengamatan langsung di lapangan produksi untuk mendapatkan data jenis-jenis waste dan non-value added activity yang dihasilkan dalam setiap aktivitas produksi.

b. Wawancara dengan supervisor dan operator untuk mengetahui lebih dalam mengenai permasalahan yang terjadi beserta hambatan yang dihadapi.

Sedangkan untuk data sekunder didapatkan dari studi literatur, antara lain dari buku, electronic book, jurnal-jurnal dan tesis yang relevan dengan topik lean manufacturing, cost reduction dan customer perceived value. Selain itu untuk kebutuhan proses validasi model, direncanakan akan menggunakan data sekunder berdasarkan kasus pada perusahaan manufaktur. Pada penelitian ini tidak mencakup tahap validasi model. 


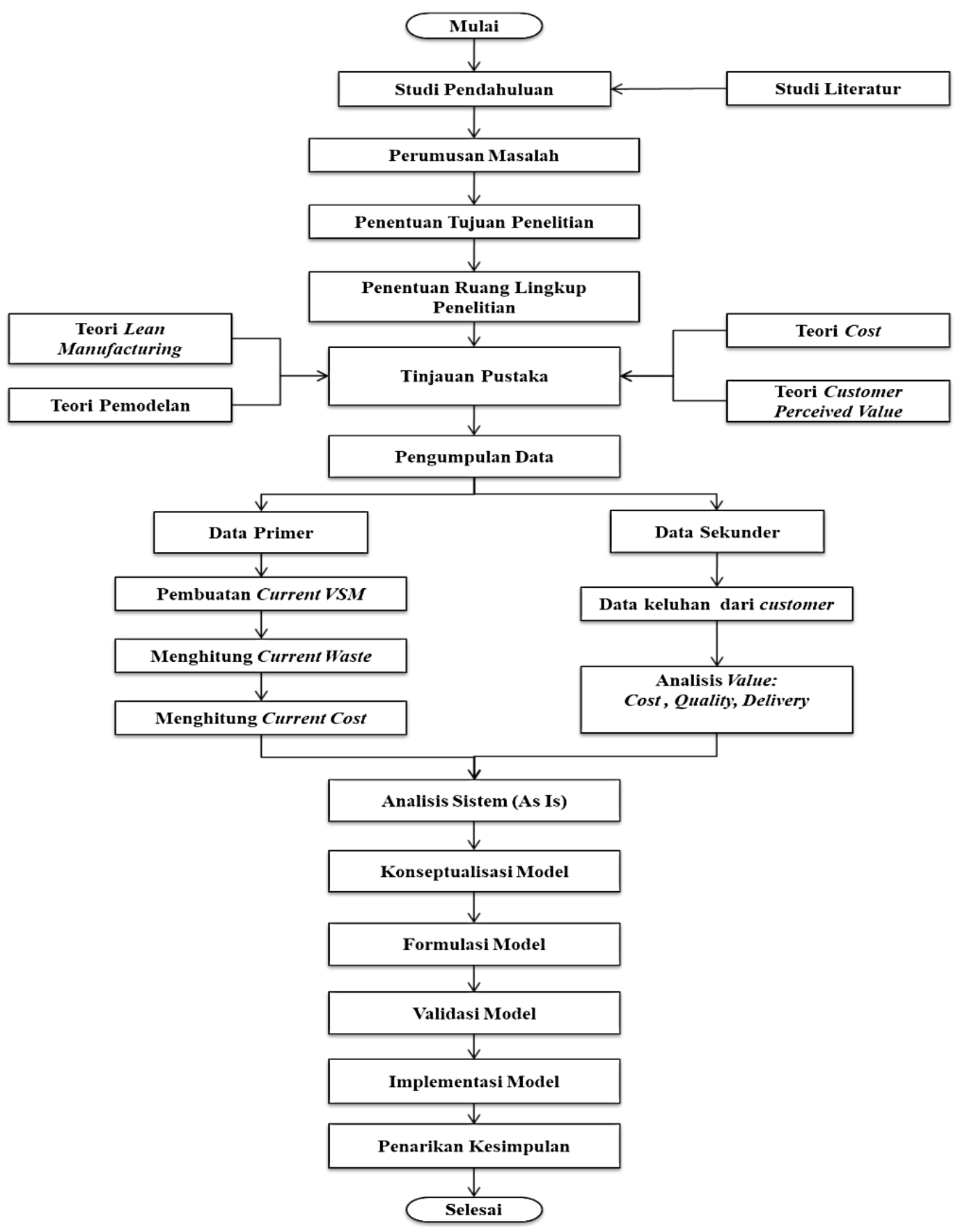

Gambar 2. Diagram Alir Tahapan Penelitian

\section{HASIL DAN PEMBAHASAN}

Perancangan model lean dalam penelitian ini cukup luas cakupannya sehingga tahap konseptualisasi model dibagi menjadi 4 sub model untuk mempermudah pemahaman. Setiap sub model yang dibuat berupa diagram alir dari mulai input, proses sampai output yang dihasilkan. Konseptualisasi 4 sub model ini akan digabungkan menjadi big picture rancangan model lean untuk mereduksi biaya dan meningkatkan customer perceived value.
Konseptualisasi sub model pertama difokuskan pada analisis current value yang dihasilkan. Diagram alir untuk sub model 1 ini dapat dilihat pada Gambar 3.

Setelah konseptualisasi sub model 1, dilanjutkan dengan tahapan formulasi sub model 1 untuk merumuskan makna diagram alir. Input pada sub model pertama ini adalah identifikasi produk value. Langkah selanjutnya adalah melakukan proses analisis current value, dimana 3 parameter value yang digunakan 


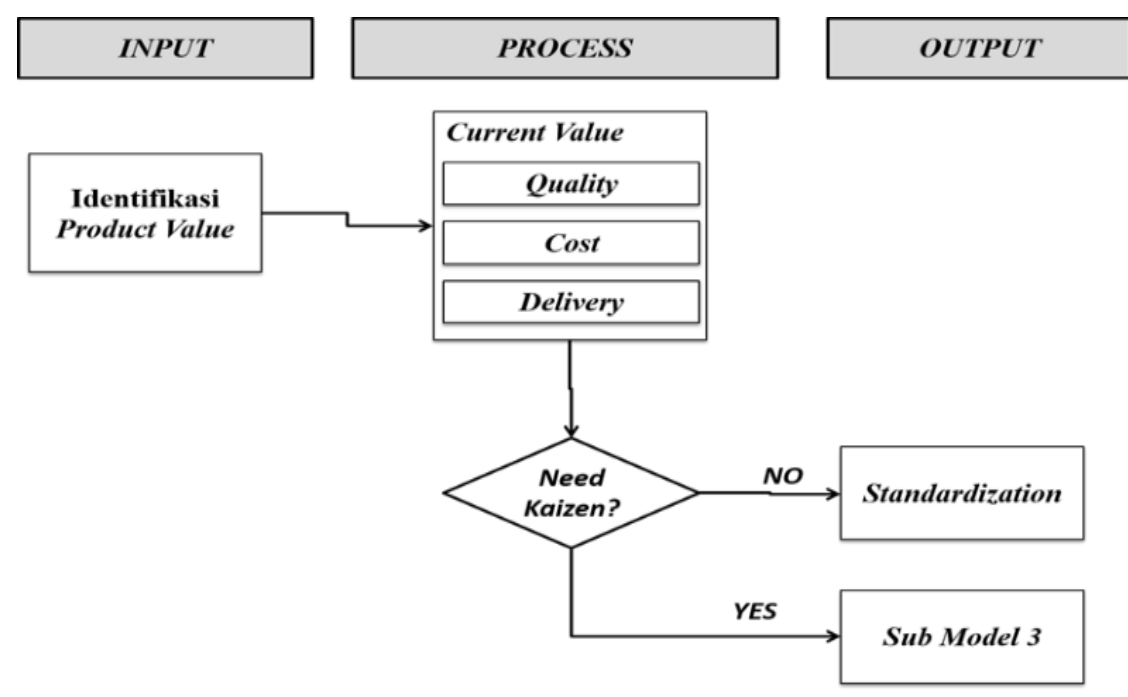

Gambar 3. Diagram Alir Sub Model 1 (Current Value)

adalah quality, cost, dan delivery. Quality menjadi parameter pertama dimana konsumen dalam membeli suatu produk pasti akan sangat memperhatikan kualitas produk yang akan dibeli. Parameter kedua adalah cost dimana harga jual dari produk akan sangat mempengaruhi konsumen saat memutuskan akan membeli produk tersebut atau tidak. Selanjutnya parameter ketiga adalah delivery, dimana kebanyakan konsumen menginginkan pelayanan pengiriman yang cepat dan tepat waktu. Jika hasil dari current value analysis dirasakan sudah sesuai dan tidak memerlukan perbaikan maka bisa dilakukan proses standarisasi. Tetapi jika hasil current value analysis tidak sesuai dan dibutuhkan perbaikan maka akan dilanjutkan untuk masuk ke sub model 4 (lean tools) yang bertujuan meningkatkan value produk.

Konseptualisasi sub model kedua difokuskan pada analisis current waste yang dihasilkan. Diagram alir untuk sub model 2 ini dapat dilihat pada Gambar 4. Setelah konseptualisasi sub model 2, dilanjutkan dengan tahapan formulasi sub model 2 untuk merumuskan makna diagram alir. Input pada sub model kedua ini adalah current state value stream mapping dimana dapat diidentifikasi value added activity dan non value added activity. Dari current state VSM ini juga dapat diidentifikasi pemborosan-pemborosan yang dihasilkan.

Setelah pembuatan current state VSM sebagai input dalam sub model 2 serta identifikasi VA dan NVA, langkah selanjutnya adalah proses pembuatan fault tree analysis untuk 7 waste. Kondisi di setiap perusahaan berbeda satu dengan lainnya sehingga model fault tree analysis untuk 7 jenis waste bisa saja tidak digunakan semuanya.

Konseptualisasi sub model 3 difokuskan pada pemilihan lean tools yang akan digunakan berdasarkan input dari sub model 1 (current value) dan sub model 2 (current waste). Diagram alir untuk sub model 3 ini dapat dilihat pada Gambar 5.

Setelah konseptualisasi sub model 3, dilanjutkan dengan tahapan formulasi sub model 3 untuk merumuskan makna diagram alir. Ada 8 lean tools yang umum digunakan dalam lean manufacturing dan digunakan dalam rancangan model ini, yaitu Kanban, SMED, TPM, 5S, Production Levelling, Pokayoke, GT Layout dan TQM. Pemilihan lean tools untuk mereduksi waste sangat bergantung dengan situasi dan proses yang ada di perusahaan.

Kondisi waste antara perusahaan yang satu dengan lainnya bisa saja berbeda. Misalkan di tempat studi kasus dilakukan banyak dihasilkan waste defect yang setelah dilakukan fault tree analysis banyak disebabkan oleh mesin produksi yang tidak produktif dan efisien. Dari analisis tersebut salah satu kaizen tools yang dipilih adalah Total Productive Maintenance (TPM) untuk memperbaiki kinerja mesin sehingga hasil lebih produktif dan bisa mengurangi waste defect yang dihasilkan. Mungkin di perusahaan lain juga mengalami waste defect, tapi setelah dilakukan fault tree analysis ternyata faktor yang menyebabkan 
adalah human error sehingga kaizen tools yang dipilih adalah pokayoke. Kondisi pemilihan lean tools untuk mereduksi waste dapat ditentukan berdasarkan hasil analisis waste dalam fault tree anaylsis yang ada pada sub model 2. Penentuan lean tools untuk masingmasing faktor penyebab dari setiap waste dapat dilihat pada Tabel 1.

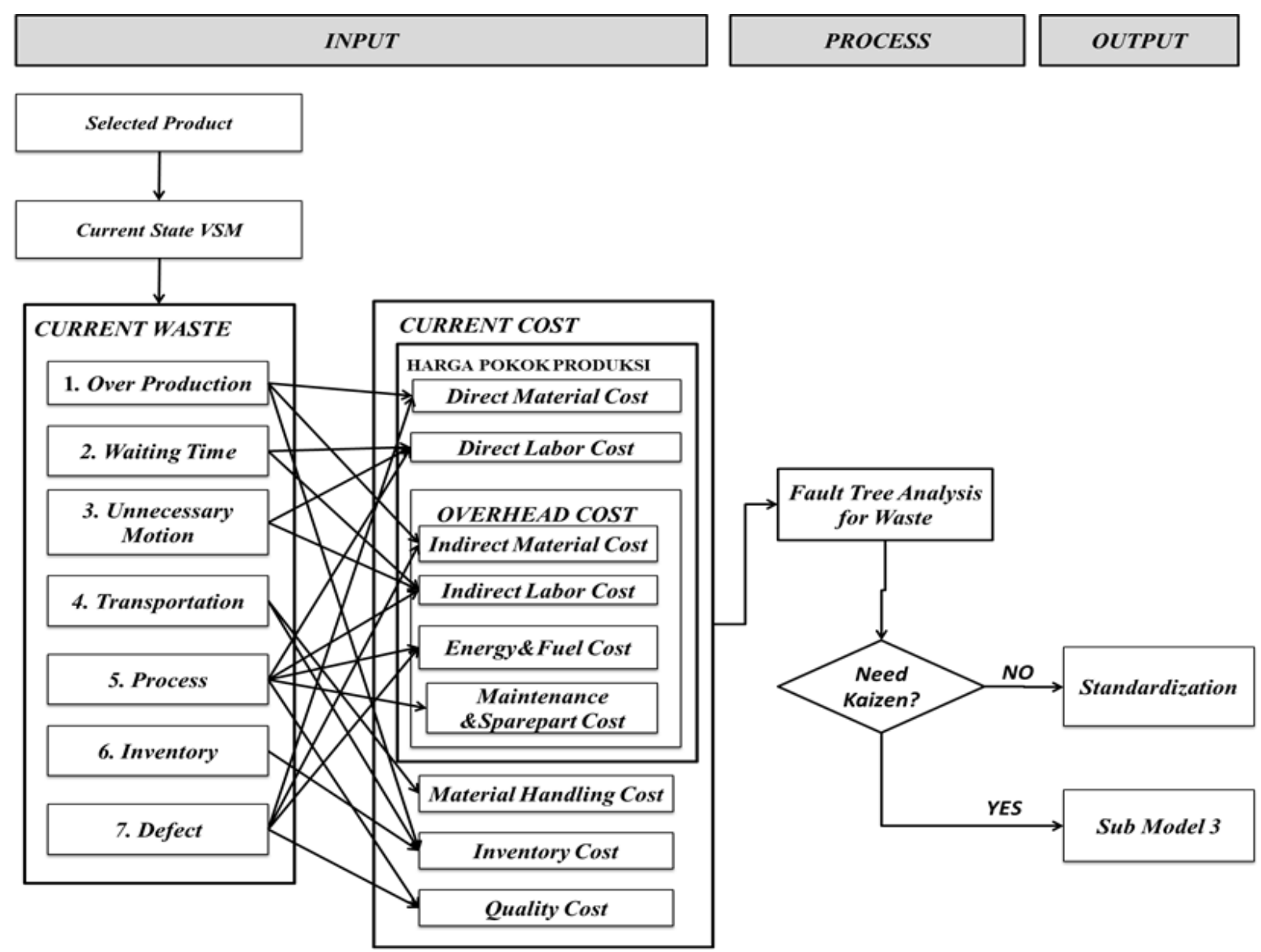

Gambar 4. Diagram Alir Sub Model 2 (Current Waste)

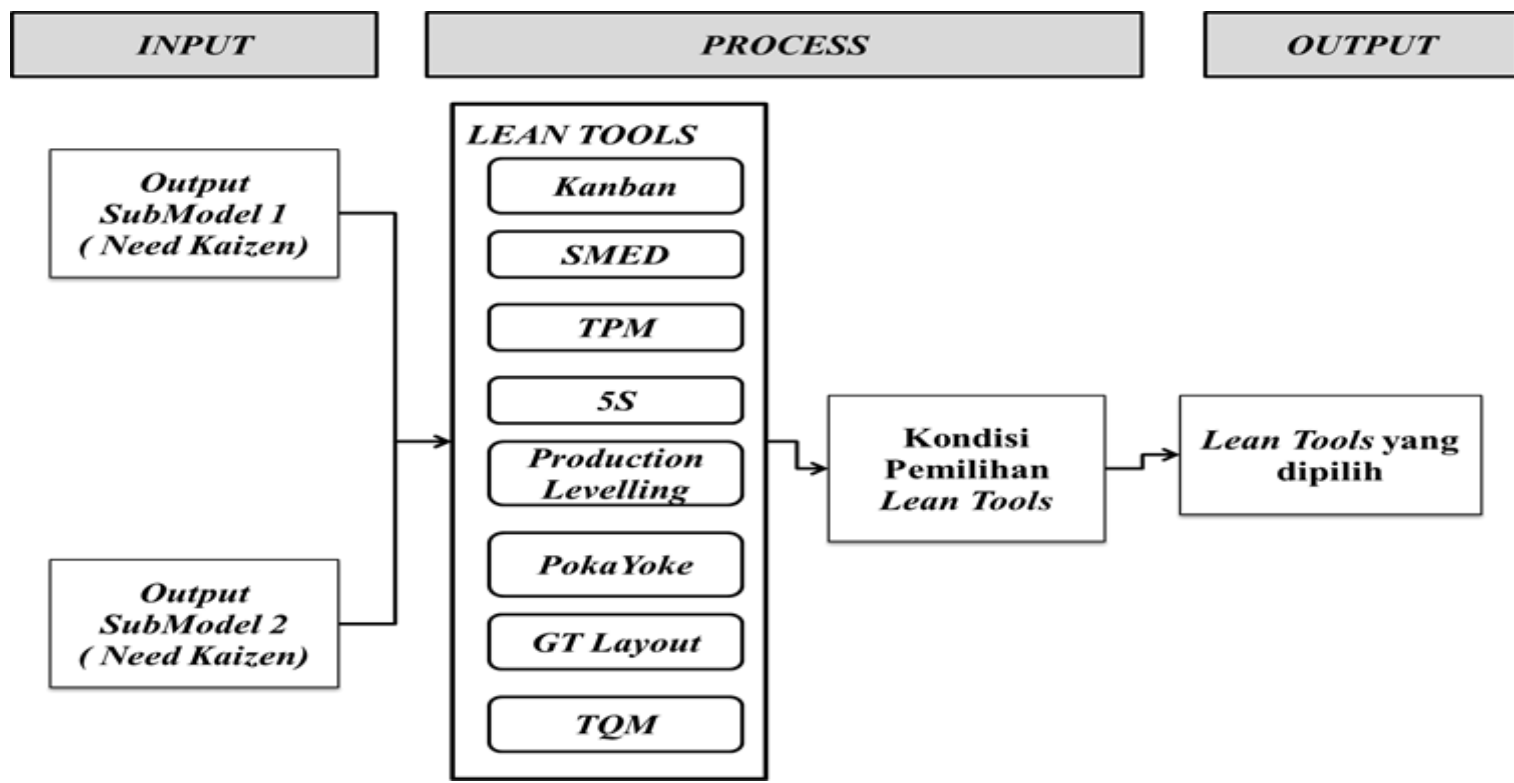

Gambar 5. Diagram Alir Sub Model 3 (Lean Tools) 
Tabel 1. Kondisi Pemilihan Lean Tools

\begin{tabular}{|c|c|c|}
\hline Waste & Fault Tree Analysis & Lean Tools \\
\hline \multirow[t]{3}{*}{ Over production } & Poor Layout & GT layout \\
\hline & Unstable Scheduling & Production levelling \\
\hline & $\begin{array}{l}\text { Prefer machine operation than material } \\
\text { usage }\end{array}$ & Production levelling \\
\hline \multirow[t]{4}{*}{ Waiting time } & Poor layout & GT layout \\
\hline & Machine setup & SMED, TPM \\
\hline & Not levelled scheduling & Production levelling \\
\hline & Poor maintenance & TPM \\
\hline \multirow[t]{3}{*}{ Transportation } & Poor layout & GT layout, $5 S$ \\
\hline & Double handling & Kanban \\
\hline & Transportation equipment problem & $T P M$ \\
\hline \multirow[t]{2}{*}{ Process } & Non value added activity & $5 S$ \\
\hline & Human error & Pokayoke, Kanban \\
\hline \multirow[t]{3}{*}{ Inventory } & Production & Production levelling, GT Layout \\
\hline & Demand & Production levelling \\
\hline & Warehouse & GT layout \\
\hline \multirow[t]{3}{*}{ Motion } & Poor layout & GT layout, $5 S$ \\
\hline & Working area & $5 S$ \\
\hline & Working method & $5 S$ \\
\hline \multirow[t]{3}{*}{ Defect } & Human error & Pokayoke, Kanban \\
\hline & Production machine & $T P M$ \\
\hline & Quality control & $T Q M$ \\
\hline
\end{tabular}

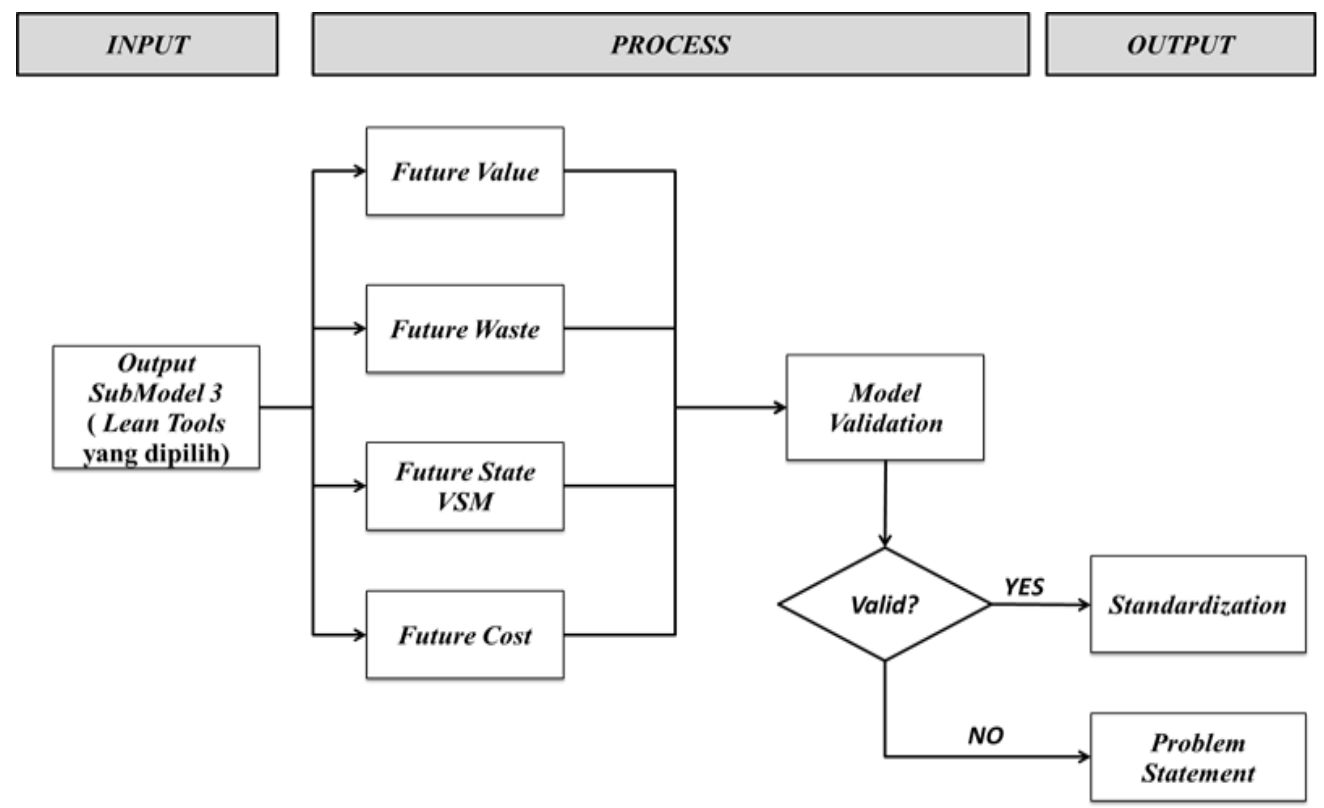

Gambar 6. Diagram Alir Sub Model 4 (future value, waste, VSM, cost)

Dengan penerapan lean tools untuk mereduksi waste, akan berdampak langsung terhadap penurunan biaya dan peningkatan value produk. Perusahaan yang operasionalnya berjalan efisien akan menghasilkan waste yang minimum dan cost yang rendah, hal ini secara tidak langsung membuat perusahaan dapat lebih berdaya saing dan memberikan harga jual produk yang lebih kompetitif dibandingkan kompetitornya. Dengan turunnya biaya harga pokok produksi, biaya material handling, biaya inventori serta biaya kualitas maka secara tidak langsung akan memberikan peningkatan value produk kepada konsumen khususnya pada parameter quality, cost, dan delivery. 
Konseptualisasi sub model 4 difokuskan pada analisis future value, future waste, future state VSM dan future cost. Diagram alir untuk sub model 4 ini dapat dilihat pada Gambar 6 . Setelah konseptualisasi sub model 4, dilanjutkan dengan tahapan formulasi sub model 4 untuk merumuskan makna diagram alir. Hasil input dari sub model 3 akan dilanjutkan ke proses analisis future value, future waste, future state VSM dan future cost. Setelah itu akan dilanjutkan ke proses validasi model yang dalam penelitian ini dilakukan di salah satu proses produksi perusahaan manufaktur.

Jika hasil validasi model adalah valid, maka dapat dilakukan standarisasi. Tapi jika ternyata hasil belum valid maka perlu dilakukan proses kembali dari awal. Dari hasil penerapan lean tools akan dihasilkan:

1. future value menunjukkan peningkatan value dibandingkan current value

2. future waste menunjukkan penurunan waste dibandingkan current waste

3. future state VSM menunjukkan penurunan non value added acitivity dibandingkan current state VSM.

4. future cost menunjukkan penurunan cost dibandingkan current cost

Big picture untuk rancangan model lean secara keseluruhan yang merupakan gabungan 4 sub model untuk mereduksi cost dan juga meningkatkan customer perceived value dapat dilihat pada Gambar 7.

Rancangan model lean dimulai dari problem statement, yaitu high waste, high cost dan low customer perceived value. Setelah ditentukan produk yang bermasalah maka selanjutnya dilakukan proses paralel untuk identifikasi product value (quality, cost dan delivery) dan identifikasi non-value added

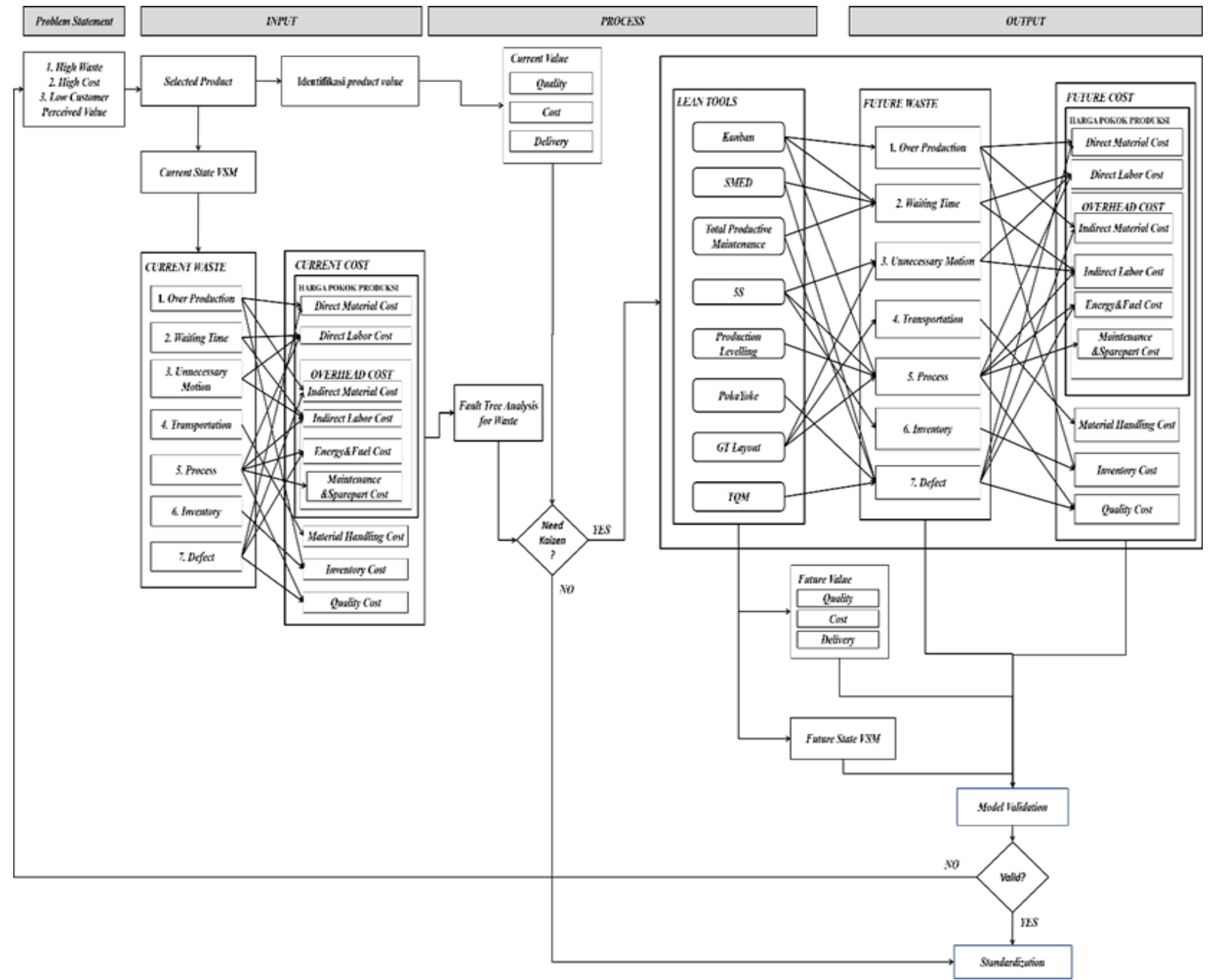

Gambar 7. Big Picture Rancangan Model Lean 
activity melalui pembuatan current state VSM. Dari hasil current state VSM maka akan teridentifikasi current waste apa saja yang muncul yang berdampak langsung terhadap current cost.

Dari hasil identifikasi current value dan current waste maka dilanjutkan ke proses pemilihan lean tools yang sesuai. Pemilihan lean tools yang tepat akan berdampak langsung menurunkan waste yang pada akhirnya kan menurunkan cost. Dari hasil penerapan lean tools maka akan didapatkan future value dan future state VSM dimana cost akan turun dan value akan meningkat. Jika hasil validasi sudah valid maka bisa dilakukan standarisasi, tetapi jika hasil validasi belum valid maka proses perlu kembali dilakukan dari awal.

Hasil rancangan model lean ini tidak terbatas hanya dapat digunakan untuk suatu perusahaan manufaktur di bidang tertentu saja. Akan tetapi model ini dapat dipergunakan secara luas oleh semua perusahaan manufaktur yang bergerak di berbagai bidang. Model lean ini juga bisa diterapkan pada perusahaan yang bergerak di bidang jasa. Dengan situasi dan kondisi yang berbeda di setiap perusahaan, maka model ini tetap dapat dipergunakan untuk mengatasi permasalahan tingginya waste. Dengan mereduksi waste menggunakan model ini maka akan berdampak langsung terhadap penurunan cost dan juga meningkatkan value dari produk yang dihasilkan, sehingga perusahaan akan semakin efektif dan efisien serta lebih berdaya saing.

\section{KESIMPULAN}

Rancangan model lean dibagi menjadi 4 sub model yang memiliki peranan masingmasing. Sub model pertama fokus pada identifikasi current value. Sub model kedua fokus pada identifikasi current waste dan current cost. Pada sub model ketiga fokus pada penerapan lean tools berdasarkan input dari current value dan current waste. Dan pada sub model keempat akan menghasilkan future value dan future cost setelah penerapan dari lean tools.

Model lean ini tidak terbatas hanya dapat digunakan untuk suatu perusahaan manufaktur di bidang tertentu saja. Akan tetapi model ini dapat dipergunakan secara luas oleh semua perusahaan manufaktur yang bergerak di berbagai bidang. Model lean ini juga bisa diterapkan pada perusahaan yang bergerak di bidang jasa. Dengan situasi dan kondisi yang berbeda di setiap perusahaan, maka model ini tetap dapat dipergunakan untuk mengatasi permasalahan tingginya waste. Dengan mereduksi waste menggunakan model ini maka akan berdampak langsung terhadap penurunan cost dan juga meningkatkan value dari produk yang dihasilkan, sehingga perusahaan akan semakin efektif dan efisien serta lebih berdaya saing.

\section{DAFTAR PUSTAKA}

[1] Karim, M.A, 2011, Implementation of Lean Manufacturing in Saudi Manufacturing Organisations: an empirical study, Advanced Materials Research-Proceedings of the 2011 International Conference on Materials and Products Manufacturing Technology (pp. 250-253).

[2] Wahab, ANA, 2013, A Conceptual Model of Lean Manufacturing Dimensions, Procedia Technology 11 (pp.1292-1298). The $4^{\text {th }}$ International Conference on Electrical Engineering and Informatics.

[3] Chahal, Virender, 2012, An Advance Lean Production System In Industry To Improve Flexibility And Quality In manufacturing By Implementation of FMS \& Green Manufacturing, International Journal of Emerging Technology and Advanced Engineering, ISSN 2250-2459, ISO 9001:2008 Certified Journal, Volume 2.

[4] Mourtzis, D \& Papathanasiou, 2016, Lean Rules Identification and Classification for Manufacturing Industry, Procedia CIRP 50 (pp.198-203), 26 $6^{\text {th }}$ CIRP Design Conference.

[5] Arslankaya, Seher \& Hatice Atay, 2015, Maintenance management and lean manufacturing practices in a firm which produces dairy products, Procedia Social and Behavioral Sciences 207, 11th International Strategic Management Conference. 
[6] Cherrafi, Anass et al, 2016, The integration of lean manufacturing, Six Sigma and sustainability: A literature review and future research directions for developing a specific model, Journal of Cleaner Production 139 (pp. 828-846).

[7] Womack, James P, Jones, Daniel T, 1996, Lean Thinking: Banish Waste and Create Wealth In Your Corporation, Simon \& Schuster, New York.

[8] Ohno, T, 2010, Sistem Pengeluaran Toyota: Melangkaui Pengeluaran Skala Besar / Karya Taiichi Ohno; Penterjemah Muhammad Syariff Paridudin, MOVE Associates, Petaling Jaya, Malaysia.

[9] Liker, Jeffrey K, 2004, The Toyota Way: 14 Management Principles from The World's Greatest Manufacturer, McGrawHill, New York.
[10] Venkataraman K, 2014, Application of Value Stream Mapping for Reduction of Cycle Time in a Machining Process, Procedia Materials Science 6 (pp. 11871196). 3rd International Conference on Materials Processing and Characterisation.

[11] Daellanbach, Hans G \& Donald C McNickle, 2005, Management Science: Decision Making Through Systems Thinking, University of Canterbury, Christchurch, New Zealand, Palgrave Macmillan.

[12] Sterman, John, 2000, Business Dynamics: Systems Thinking and Modeling for a Complex World, McGraw-Hill. 